\title{
Correspondence.: The Tactical Employment of Pack Artillery: A. Criticism
}

\section{J. G. Geddes \& Major E. F. A.}

To cite this article: J. G. Geddes \& Major E. F. A. (1906) Correspondence.: The Tactical Employment of Pack Artillery: A. Criticism, Royal United Services Institution. Journal, 50:339, 721-723, DOI: 10.1080/03071840609416802

To link to this article: http://dx.doi.org/10.1080/03071840609416802

曲 Published online: 11 Sep 2009.

Submit your article to this journal $\widetilde{ }$

Џ Article views: 4

Q View related articles $\sqsubset$ 
"But the most efficacious fire itself should not be sufficient to turn a tenacious enemy out of his positions. Experience proves that the fire fight may be kept up for hours at a range of 400 yards. $\Lambda$ courageous enemy does not yield except to an actual bayonet attack. The more 110 is convinced that he exposes himself to destruction if 'he rises and retires, if he abandons the position, the longer will he remain before sielding. We should not give up the bayonet attack in close order, for it constitutes, and will alwass constitute, the crowning of the edifice. In this regard there is always one primordial condition, riz. : that the men must have confidence in the arme blanche, and that they should be trained to bayonet fighting in peace time. This training forms the moral counterpoise to all improvements in fire-arms. I also openly assert that bayonet fighting should be more rationally and more frequently practised. The basis of success lies not merely in the training of a man as a marksman, hut in the individual perfecting of all his faculties; that is to sas, that equal importance should be attached to shooting, bayonet fighting, and to the use of the spade."-Internationale Rerue iuber die Gesamten Armeen und Flotten.

\section{CORRESPONDENCE.}

\section{THE TACTICAL EMPLOYMENT OF PACK ARTILLERY : A . CRITICISM.}

To the Editor of the Jormat of the Roval UNited Senvice Institetiox.

Sir,-Major K. K. Knapp, R.G.A., in Vol. L., No. 836, Jounxal of the Royal United Service Institution, published 15th February, 1906, in an article under the above heading, makes certain suggestions regarding "Pack" or "Mountain" Artillers, which appear open to criticism. This I renture to offer in a friendly spirit.

Major Knapp's suggestions are, briefly :-

1. One mountain battery should be added to each brigado of infantry, or in the case of an army corps of three divisions, two brigades of mountain artillery should belong to the corps artillery, and that, should this scheme be carried out, an equivalent amount of field artillery be withdrawn.

2. That the mountain batteries should be "Brigade" and not "Divisional" Artillery.

3. That the only brigade of horse artillery on the establishment of an army corps should be abolished, and replaced by a heavy artillery brigade.

1. As regards the first suggestion, Major Knapp, in his second paragraph, says:- "It would be unsound to adrocate the use of mountain guns in places where wheeled artillery can be equally well employed, but there must be undoubtedly many occasions even in European varfare when pack artillery would be of value on account of its great mobility. 
Batteries of guns carried on pack animals. . . . can easily negotiate hills, woods, broken or close country, which would be difficult, if not impassable to wheeled artillery, unless roads exist or passages have been previously prepared."

Few will caril at the truth of the foregoing, but it is difficult to realise how the writer can reconcile the above with the suggestion that two brigades of mountain artillery should accompany an army corps on all occasions.

On fair roads and good country the traction power of any animal is of far greater value than his carrsing power. The disappearance of the pack horse from England and most European countries exemplifies this. Artillery will therefore never be carried, on the backs of men or animals if it can possibly bo moved on wheels.

Tho difficult nature of ground in Afghanistan, the frontiers of India, and Manchuria, over which armies aro at times forced to move, alone caused the necossity for "pack artillery:" Under normal conditions of warfare in Europe, Africa, and India, wheeled artillery can accompany any force.

For fighting under abnormal conditions, pack artillery may bo a necessity. Manchuria is without doubt a country in which pack artillery is very valuablo; but oren so, why should we cater in our normal establishments of an army corps for an abnormal stato of affairs, and turn nearly 30 per cent. of our field artillery into "pack" artillery?

$A$ s regards the relative values of the gun, an army corps commander would hardly agree to exchange no less than thirty-six 18-pounder Q.F. field guns for a similar number of 10-pounder mountain guns, unless the nature of the country was so rugged that this loss of gun porrer ras forced upon him.

The admission, therefore, of pack artillery into any force is entirely a question of the nature of the country. It exists where it is required, viz., on the Indian Frontier.

2. As regards the suggestion that each infantry brigade should have a mountain battery belonging to it, Major Knapp builds up his arguments on the statement that pack artillery is peculiarly suited to mork with infantry-

a. Because of its mobility:

$b$. Because it can talie more advantage of corer.

c. Because it cain support infantry moro closely.

Concerning mobility, I dișagree with Major Knapp's interpretation of the term mobility. $\Lambda$ mobile column is usually taken to mean a column which can more rapidly. If field artillery can bo taken into action, even at a walk, it must be preferable to tho lighter equipment throwing a smaller projectile. To support infantry, flank marches may hare to be made by àrtillery at a rapid rate, which mountain artillery could not do, unless the nature of the country is so rough as to prohibit the use of wheeled artillery. Therefore, one cannot agree with the statement: "With the addition of batteries of pack artillery the necessity for the brigade of horse artillery (with an army corps) will cease to exist."

Conccalment.-It is obvious that pack artillery can conceal them. selves behind cover which would offer no concealment to wheeled artillery, before opening fire, such as low hedgés, standing corn, and such liko, but from a position behind a hill corer can usually be obtained by any naturo of artillery. But when in action the pack artillery may find itself opposed to Q.F. field guns of far greater reight of metal and possessed of shields. 
The contest would be most unequal and the result inevitable, viz., that the infantry would not get any support from their mountain guns, which must be silenced.

If, therefore, artillery desire to support infantry they must be prepared to face the fire of modern Q.F. field artillery, unless the nature of the country is such that wheeled artillery cannot be made use of.

The question of having the bulk of the artillery with an army corps "divisional," and not part and parcel of infantry brigades, has been settled, principally on account of the difficulty of ensuring combined action on the part of the guns when required. Under our present system, a battery or a brigade can almays be attached to an infantry brigade, if required for any special purpose.

In operations against an enemy not possessed of artillery, no doubt, the permanent dispersion of artillery units is to be recommended.

For example (to quote from a report on the recent German South African campaign against the Hereros, where dispersion of artillery eren by sections in stationary camps, on the march, or in action took placo), we read: "This dispersion is moreover without danger so long as the Hereros do not possess artillery." This points to the fact that other European Powers regard the permunent dispersion of artillery units with disfavour.

3. Major Knapp's proposal to abolish the only brigade of horse artillery with an army corps has been touched upon under the remarks on "Mobility." Tho addition of a brigade of heavy artillery would in no way compensate for the loss of this mobile unit. Nor does his consideration contained at the end of his sixth paragraph clear up the situation: "It is a matter for consideration whether it would not be advisable to add a second (horse artillery) brigade to the strcngth of a division of cavalry."

Now, to saddle a caralry division with two brigades of horse artillery permanently would, in these days of $Q . F$, batteries and consequent increase in ammunition wagons, considerably hamper the free movement of the division, and cause its commander much anxiety. Under existing conditions the horse artillery with a cavalry brigade can be augmented by attaching to it horse artillery, from the corps artillery; but it is thought that such augmentation mould only be desirable to meet special purposes.

Tactical Employmcnt.-As regards the tactical employment of " pack" or mountain artillery, it would appear (from Major Knapp's quotations from "Combined Training") that the same broad principles which govern the employment of wheeled artillery, apply equally to pack artillery.

To conclude, I entirely agree with Major Knapp that a mountain artillery unit (or units) should be maintained at home for use with an expeditionary force, if called upon to operato in a country necessitating the employment of pack artillery; but $I$ strongly deprecate turning any portion of the Q.F. field artillery allotted to an army corps into pack artillery or substituting a brigade of heavy artillery for the brigado of horse artillery with the corps artillery: Finally, I consider that "Combined Training" deals sufficiently with the tactical employment of artillery in the field, whether it is pack or wheeled artillery.

\section{Hilsea,}

J. G. Gendes, Major, R.F.A.

Warch 8th, 1906. 